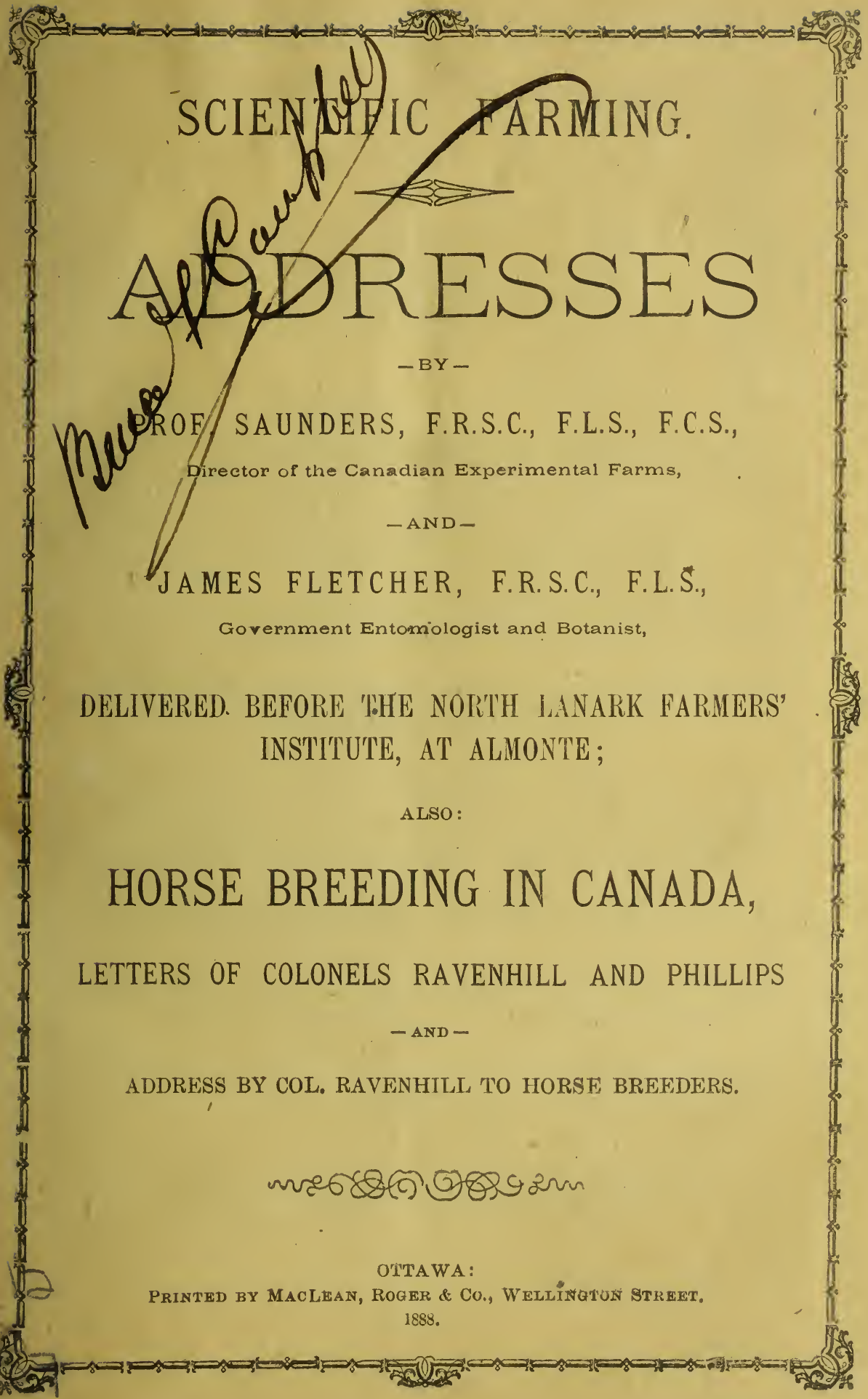


The EDITH and LORNE PIERCE COLLECTION of CANADIANA

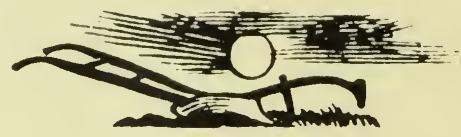

2ueen's University at Kingston 


\section{SCIENTIFIC FARMING.}

AD
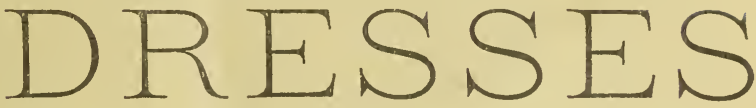

$-\mathrm{BY}-$

PROF. SAUNDERS, F.R.S.C., F.L.S., F.C.S., Director of the Canadian Experimental Farms,

JAMES FLETCHER, F.R.S.C., F.L.S.,

Government Entomologist and Botanist,

DELIVERED BEFORE THE NORTH LANARK FARMERS' INSSTITUTE, AT ALIIONTE;

ALSO :

\section{HORSE BREEDING IN CANADA,}

LETTERS OF COLONELS RAVENHILL AND PHILLIPS

ADDRESS BY COL. RAVENHILL TO HORSE BREEDERS.

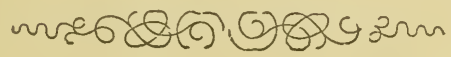

OTTAWA :

Printed by Maclean, Roger \& Co., Wellington Street. 1888. 
Digitized by the Internet Archive in 2013 
[Erom the Ottawa Daily CitiznN, Dec. 15th, 1887.]

\section{THE DOMINION OERTRAL EXPERIMENTAL PARMI.}

In to-day's issue we publish a report of the proceedings of the annual meeting of the North Lanark Farmers' Institute, held at Almonte, a few days ago, in which will be found matter of great interest to agriculturiste, and incidentally to the community in general.

The address of Professor Saunders is marked by the clearness which his utterances and writings are known to possess, and it certainly affords an answer to the question which is often asked; What is the use of Experimental Farms? He shows that they were first established by associations of farmors in Germany, who saw the need for the work they could do; they were afterwards taken up by the Government of that country; and thence they soon spread to other countries which have made any advance in agriculture. There are many exporiments in practical acriculture which are impor. tant to every farmer, but which every farmer has neither the leisure nor the facility to try. It is, therefore, in the common interest, and we use this term in the widest sense, for the furming interest affects the whole ciuntry, that these exporiments should be tried by the Government; and the furraing population afforded the advantage of the results. We think the Gorernnent of Sir John A. Macdonald may fairly be congratulated upon the progress which has been already made and which is so clearly described in the address of Mr. Saunders. And it cannot bo without interest to the Premier's constituents in Carleton that the Central Experimental Farm for the Provinces of Quebec and Ontario should bo established in their county. It must also bo a matter of congratulation for the Hon. John Carling, the Minister of Agriculture, to seo the very successful working of one of his most cherished projects. Still further, the farmers of the country may be congratulated on the fact that prac$1 \frac{1}{2}$ 
tical agriculture is boing intelligently and actively treated as an applied science by the Government of tue Dominion, in such a way as to keep it abreast, if not to place it in the front rank, with the best practice in agriculture in other countries, instead of being allowed to drift along as best it might by the light of the sometimes effective, perhaps, rule of thumb, or experiments of individual farmers, very often conducted under difficultios. One practical benefit which appears to be clear in the steps already taken, is that a new wheat has been imported, which is described as being almost the equal of the Red Fife in hardnoss and excellence, but which has, for parts of this Dominion, the almost inestimable value of ripening from one to two weeks earlier. If this wheat had been available in Manitoba and the districts of the North-West in the years 1883 and 1884, it would have prevented what was really a calamity; and it may be broadly stated that the introduction of this wheat alone greatly outweighs in value to the country all the expenditure which has been made, or we might almost say, which can be made, on the Experimental Farms. Prof. Saunders shows that many grains and roots have a tendency to run out, and if practical information is afforded to farmers on this point, it cannot fail to be of great importance to them. We, ourselves, hope greatly for the results from the horticultural experiments which have been set on foot. If these succeed in furnishing information to the farners of the old Provinces of the particular fruit trees which are better adapted to their circumstances than those at present found, the country will be made both richer and more pleasant to live in thereby. This remark even more strongly applies to Manitoba and the North-West. There the lack of fruit trees is a great deprivation. But it is believed that those varieties which succeed in Northern Russia will succeed there; and this, we understand, will be tried by the experiments now being conducted under Professor Saunders' direction. And even in the matter of seed testing, if farmers in Canada can, in many instances, as they have been in other countries, be saved from the evil consequences of Eowing seeds of which a sufficient percentage will not germinate, both they and the country will be saved from loss. Prof. Saunders 
shows that a good beginning has been made in this respect, and that losses have been prevented. These tests are easily available; Arrangements have boen made with the Pust Office Department for the transmission of the seeds, and each farmer is promptly informed of the value of the specimens sent by him for examination. There are many other points in the report before us which we are tempted to enlarge upon, but our object is less to refer in detail to the matters so clearly stated in the address as to direct attention to it.

The address of Mr. James Fletcher, the Dominion Entomologist and Botanist, also contains matter of great interest and importance to farmers; we can only, however, in this place, direct attention to it. 


\section{LANARK FARMERS.}

ANNLAL MEETING OF THEIR INSTITUTE FUR BUSINESS PURPOSES.

ADDRESSES BY

PROF. SAUNDERS AND MR. JAIES FLETCHER OF THE

Government Central Experimental Farm, Ottawa.

QUESTIONS OF GREAT INTEREST DISCUSSED.

(From the Report in the Ott\&wa Daily Citizan, December 15, 1887.)

Almonte, 10th.-The annual meeting of the North Lanark Farmers' Institute for the election of officers and other business was held in the Town Hall here to-day. Mr. C. M. Simp*on, President of the Institute, presided, assisted by Mr. John Steele, Secretary.

After some preliminary discussions by members of the society an address was delivered by Prof. Saunders, F.R.S.C., the Director of the Government Experimental Farms.

EXPEIMENTAL AGRICULTURE AND ITS VALUE TO THE FARMERS.

Prof. Saunders said: It affords me a great deal of pleasure, indeed, to be with you to-day, a double pleasure for the reason that last year when your Secretary was kind enough to invite me to 
come to your annual meeting, and I had made every arrangement to attend, the evening before I was attacked with a violent illness which confined me to my bed for some days. I have listened with much interest to your discussion of subjects connected with farming which are of so much importance to yourselves and to the country. I think it is a good sign when institutes of this kind are co well patronized and so well attended, notwithstanding the inclemency of the weather; whon farmers meet together to discuss the results of their own experience, the character of the crops they have grown under different conditions of soil, and different circumstances, and compare notes and thereby benefit each other by the interchange of ideas in all such mattors. It indicates that a community of this sort consists of thinking men. A farming community that exercises itself in that direction will always be a prosperous one, and will be well to the front in all departments of agricultural work.

\section{AGRICULTURE AND EXPERIMENTAL SCIENCE.}

Agriculture is and always has been an experimental science, and in the vers nature of the subject it must always be. Most of the experience we have in agriculture has been obtained by the practical experimenting of individual farmers, a few facts gleaned here and there, and these added into one great sum constitute our present knowledge of the art. Up to within a recent period very little had been done either by socioties or by Governments to aid individual effort in this particular line of work. It was only about thirty years ago that the first agricultural experimental station was established in Gormany, and this was the first effort made in any part of the world to bring to bear on farming operations the benefits of scientific training. A number of farmers met together in one of the provinces of Germany and there resolved to establish an experimental farm on a small scale in order to save them individually the cost and trouble of each one experimenting for himself. They selected a manager for this farm, and started a course of experiments, and shortly after applied to the Government to help them in the matter. The Government inquired into the subject, and believ. 
ing that the scheme was a good one, and that it was likely to produce excellent results, voted a sum of money to aid in the work. Within a few years several similar institutions were started in other parts of Germany, and they have gained in popular favour from year to year nntil now. In most cou ntries in Europe holding any. thing like an advanced position in agriculture, there are many of those experimental institutions where scientific work is carried on regularly, the results are giving to the farming community, and they reap the benefit of the experience so gained for them. From the outset the cost and maintenance of these institutions has been borne almost entirely by the Government of the country in which they are located.

THE VALUE OF SCIENTIFC EXPERIMENTS TO THE FARMER.

It has often been asked, "Of what practical use a re those institutions to the farmer?" Well, there are many experiments which could and should be carried on to benefit the agriculturists which demand more time, more risk and more careful attention than farmers can afford to give, and the use of apparatus which farmers have not at their command in order to $\mathrm{w}$ ork out satisfactorily all the details connected with the tests, so that there are classes of experiments which farmers cannot well undertake for themselves, and which are of great value to the community.

\section{CLOVER AS AN ACCUMULATOR OF NITROGEN.}

There is not a farmer present, I presume, but knows the value of clover as a green manure. It is a subject that everyone is familiar with, and there is, perhaps, no plant at present known which is so valuable an agent in nourishing the soil as a good crop of clover ploughed in green. If anyone a sks why it is so, he is usually met with the answer, "We know it is so, because it is the result of our experience." Now if we bring chemistry to bear on the question, wo find that clover contains a large proportion of an element which is a very important fertilizer of the soil-nitrogen. This element exists in the soil in considerable proportions. It is found in every soil, and it forms as well the great bulk of the atmosphere we 
breathe. In the soil it exists in two conditions: One form, which is called available nitrogen, is that form in which plants can take it up readily as food; while in the other form, known as unavailable nitrogen, it is locked up in the soil and cannot be assimilated as plant food until it has undergone a change, which is usually brought about in a very gradual manner by the cultivation of the soil and the exposure of every part of it to the action of the atmosphere, which gradually converts the unavailable nitrogen into the available form, and in that way the fertility of the soil is partially maintained. It has been shown by analysis that clover accumulates nitrogen in a large proportion from some source during its growth. It is not definitely known whether this nitrogen is obtained from that which is unavailable to other plants, or from the air; but it is known that a given weight of clover contains nearly fifty times as much of this valuable element, as the same weight of the wheat plant. Hence, if clover, with its weight of fertility, is ploughed under, it gives to the soil a dressing which will serve for the enriching of several succeeding crops.

\section{UNKNOWN STORES OF NITROGEN.}

The knowledge of this fact in connection with clover leads to another consideration. Clover is only one member of a very large family of plants which are known to botanists as leguminous plants, which include all the lupins, vetches, tares, \&c., some of which are natives of this country and some of foreign countries. If clover has this quality of storing up nitrogen, other plants may have the same and some a superior power in that direction, one can at once see that here is a field for experiment in a direction which would be exceedingly valuable to the whole farming community, to ascertain which of the leguminous plants, if any, are as good or better than clover for this purpose. There are some native to the north of Europe and many more found in different sections of this great Dominion, all of which should be experimented with in order to ascertain whether they could not bo made useful to agriculture, for it has been well said that the power of one plant to store up food 
for future crops of other plants lies at the vory foundation of successful agriculture. Nitrogen is sbundant in all animal fertilizers, and it is the presence of that element which gives to these fortilizers their chief value.

\section{IMPORTANCE OF PERMANENT PASTURES،}

Another point which I might use in illustration is the importance to farmers of permanent pastures for eattle. It is very uncertain, in viow of the immense fertile wheat-growing plains which we have in the North-West, whether farmers in the east will bo able to compete in grain growing with the farmers of the Prairie Provinces. Indeed it is vers doubtful if they can. In that case the farmers of Eastern Canada will have to fall back on such lines of agriculture as they can make most profitable, and one of these is stock-raising. Permanent pasture may be defined as a mixture of perennial grasses containing those which will ripen at different periods during the season. A crop of timothy ripens and is harvested early in the year, af er which thore is a long period when that field is useless for the purpose of nasture, and not until the growth is strong onough, and has body enough to provide good grazing, would a farmer thirk of pasturing his cattle on it. But in permanent pasture you get a selection of grasses, which live from year to year, some of which will ripen early in the season, some in the middle of the summer, and others later on, so that the cattle may have a succession of that succulent food which they need and hare it in such abundance as will enable them to put on flesh rapidls.

PROVIDENCE HAS NOT PLACED ALL THE GOOD GRASSES IN ANY ONE PART OF THE WORLD.

Most of the grasses which we have in cultivation have come to us from various parts of Europe, and there are some varieties in our own country which are quite as promising, perhaps, as some of the European sorts. In $m_{y}$ late journey in the North-West I paid some attention to tho native grasses, ard found varieties there which seem to me to be quite promising, judging from their habit of growth, and trom the fect that cattle show such a preference for 
them. When brought under cultivation there may be found among them species quite equal and perhaps superior in some respects to those at present in use. There are also in the North-West and in the Western States, some varietios which are capable of standing very dry weather, and some others adaptod to very cold climates. By growing judicious mixtures of these grasses, we hope to ascertain their true value. This important work will be carried on extensively at the Experimental Farm, and the object will be to show which are the best $\nabla a r i e t i e s$, bring them into notice, and also to take such stops as will make them available to farmers. There are a score or rnore different kinds of grases, which cun be obtained from sesd dealers in Europe and other countries, many of which would be exceedingly useful if their valuable qualities were better known. These facts serve to show that there are lines of experimental work which at first sight might appear trivial, but are expected in the ond to produce results of great importance to the stock intorests of this country. Such experiments cannot be undertaken by the farmer. Fow of you could afford the time or expense required to travel to the North-West and other places in search of such products; but if this can be done for you, the information obtained for your guidance, and the material made arailable for your use; you must admit that great good is likely to result from such work.

\section{DEGENERATION OF ROOTS AND OEREALS.}

All our cereals, roots and tubers are, to a great extent, artificial products. You do not find wheat, oats or barley growing anywhere in nature as we have them now! You do not find potatoes like those in cultivation growing wild. The potato originated from an insignificant wild varioty, which, by cultivation and careful hybridization, has been brought to its present high standard of excellence. So with wheat, oats and barley, and all field crops. These improved plants and roots, good as they are, are liable to constant variation and to frequent deterioration-that is, they often "run out." If you recall the varieties of grain and potatoes which were grown twenty 
years ago, you will find very fow of them to day. This points to the importance of continual exporimental work with new varieties of grain and other crops, so that by the froquent introduction (as in the caso of stock) of new blood there may bo imparted to these products that vigor of growth and fertility of oharacter which will adnit of their being cultivated to greater porfection and profit.

WASTEFUL FARMING.

Our farming during the past has not always bsen conducted in the most economical manner. Crops have somotimes not been sown with needed promptness, the fertilizers at command have not been made the best of, anu much land that would bavo yielded good results has for want of proper drainage and care remained unproductive to the owner. Loss to the country has also resulted from lack of information regarding the necessity of a proper rotation of crops. Canadian farmers will require to be more careful in these particulars if they would maintain for their country in these days of keen competition and improved appliances that well-deserved preeminence in agriculture which she has hitherto onjoyed. I might enlarge here indefinitely, but perhaps I have said enough in the few thoughts presented to show that there is practically no limit to experimental work, the results of which, when its true value is determined and made known, will be of inestimable consequence to farmers everywhere; and when I say that the experimental farms established by the Dominion Government are to take up this class of work especially, and report on it frequently for the benefit of the farmers, I think I have fairly answered the question: "What good will those farms be to the agricultural community?" The cstablishment of so many of these experimertal institutions in Earope led to the consideration of the subject in America, and about thirteon years ago the first of these experimental stations was established in the State of Connecticut. Since then a number of similar institutions have been started, supported by annual grants from the logislatures of the different States in which they have been located, until the importance of the subject has so grown on the farmers in the United 
States that for a year or two past the people have been agitating for more liberal support from the general Government for such institutions, and last yoar Congress passed a Blll known as "The Hatch Bill," which provides for an annual appropriation of nearly $\$ 500,000$ to be divided amongst the different States, to be devoted entirely to this experimental work in agriculture, horticulture and forestry. In the meantime the Canadian Government has also been looking after the interest of the farmers. In 1884 they appointed a committee to enquire into this subject, and from the opinions expressed by practical farmers, who were called before this committee, the Government were led to consider the expediency of

\section{PROVIDING EXPERIMENTAL FARMS FOR CANADA.}

Our worthy Premier, Sir John Macdonald, who always takes the warmest interest in everything that tends to the posperity of the agricultural classes, asked Parliament for an appropriation of $\$ 20$,000 towards the purchase of a site for an experimental farm. In November of that year I w2s requested by the Government to visit the different agricultural stations in the United States; and also to ascertain by correspondence the working of similar institutions in Europe, and to prepare a report for the Government which might give them such additional information as they required in order to reach some conclusion regarding this work of experimental agriculture. I travelled through all the Western and Northern States, and visited every agricultural institution located anywhere near the Canadian boundary, and submitted a report of my investigations. The result was the passage of the Bill known as "An Act respecting Experimontal Furm Stations," which provided for the establishment of five experimental farms, one of which was to be located near Ottawa, to serve the purposes of Ontario and Quebec jointly; one in the Maritime Provinces, to serve the purposes of those Provinces jointly; one in Manitoba ; one in the North-West Territories, and one in British Columbia.

\section{THE OBJECTS AIMED AT}

in establishing these farms might be better presented to you perhaps 
in the wording of the Acts itself. The work to bo undertaken is set forth as follows:

(a) Conduct reseaches and verify experiments designed to test the relative value, for all purposes, of different breeds of stock, and their adaptability to tho varying climatic or othor conditions which prevail in the several Provinces and in the North. West Turritories;

(b.) Examino into the economic questions involvod in the production of butter and cheose;

(c) Test the merits, hardiness and adaptability of new or untried varieties of wheat or other cereals, and of fiold crops, grasses and forage-plants, fruits, vegetables, plants and trees, and disseminate among persons engaged in farming, gardening or fruit-growing, upon such conditions as are prescribed by the Iinister, samples of the surplus of such products as are considered to be specially worthy of introduction ;

(d.) Analyse fertilizers, whether natural or artifial, and conduct experiments with such fortilizers, in order to test thoir comparative value as appliod to crops of diffurent kinds;

(e.) Examine into the composition and digestibility of foods for domestic animals;

(f.) Conduct experiments in the planting of trees for timber and for shelicer.

(g.) Examine into the diseases to which cultivated plants and trees are subject, and also into the ravages of destructivo insocts, and ascertain and test the most useful preventives and remodies to bo used in each case;

(h) Investigate the diseases to which domestic animals are subject;

(i.) Ascertain the vitality and purity of agricultural seeds; and

(j) Conduct any other experiments and researches bearing upon the agricultural industry of Canada, which are approved by the Minister. 
It will be seen from this category that provision is made for experimental work in all departments of agriculture in each of the Provinces. In order to carry on this work the Act authorized the employment of a Director, who was to have supervision of all the institutions ; of a Horticulturist, who was to take charge of tho department of horticulture at Ottawa; of a Botanist and Entomologist (the two offices combined), and I am happy to say that Mr. Flotcher, the gentleman appointed to that important branch, is present and will be able to speak for himself. It also provided for the appoint. ment of a Chemist, whose duty it will be to analyze fertilizors and conduct all chemical operations; and also for the appointment of an Agriculturist who shall be specially charged with the management of the field crops and stock. When the site for the Central Experimental Farm was located, possossion of it was not secured until November of last year-too late to accompli:h much, but there was found time to plough about 20 acres and gather up some loose stones that were scattered over the ground. Winter then set in and put a stop to all out-door work until the spring. In the meantime a small building was erected for an office and a glass structure in which

\section{TO TEST THE VITALITY OF SEEDS,}

which was one of the operations the Act prescribed should be undertaken. This work was successfully carricd on last winter, and 187 samples of wheat and other cereals, grass seeds and other fiold crops, were sent in to the institution to be tested. The vitality of those was determined and the percentage that rould grow under favor. able conditions reported to the farmers sending them as promptly as possible. That department of work has been of much practical value, as will be seen from the bulletin that will be issued from the farm very shortly, giving details of this work. It resulted in the farmers being saved, in many instances, from sowing seed which would have givin them very little return for their labor. In the harvesting of grain it sometimos happens that after it has been cut and put in the mow it will heat and its vitality as seed will bo injured; there are other causes also which may occur which so affect 
soed grain as to make its gormination more or less a matter of uncortainty. The Experimental Farm offors to any farmer in the Dominion the advantage of sending in, free of postage, samples of seod to be tested in the soil and also in another form, in duplicate, one test boing a check on the other, and roturns are made to the furmors without any charge or expense. I hope that the gentlemen present will all of thom arail themsolves of the advantages offered in this department of our work as freely as they think fit. We shall not complain of any number of samples being sent, and shall endeavor to meet any requisition that may be made on us in this respect. Seed testing has already begun, and we should like to have samples sent in as early as possible, so that there may not be too much of a rush as see 1 timo approaches. It sometimes takes a fortnight or three weeks to properly test the germinating power of some seeds.

\section{EARLY RIPENING WHEAT.}

Another matter undertaken during the past winter was the im. portation from Northern Russia of an early ripening wheat. Farmers in some parts of the North-West have suffered several years, some seasons much worse than others, from frozen wheat, and it was believed that if a variety of wheat could be obtained that would ripen a week earlier than any sort at present available it would result in most instances in the saving c $f$ the crop. While frozen wheat has some value, still the saving of the crop from frost would make a difference to the farmers of between $55 \mathrm{cts}$, and about $25 \mathrm{cts}$. per bushel. The new seed wheat was obtained from a district in Russia, 600 miles north of where we are to-day, and where the season is much shorter than in any of the settled portions of our Nonth-West Territories. This wheat has ripened from ten to fifteen days earlier than any other variety of wheat cultivated there. It has shown great vitality, and is believed to be rearly, if not quite equal, in every respect, to any other sortincultivation. In Ontario and Quebec it has not succeeded so well on account of the dry season we have had. In consequence of its early ripening quality it has not had quite the chance that later ripening varieties have had, 
and hence the grain is somewhat shrivelled, but in the Maritime Provinces, where they have had more moisture, it has turned out very well, so that we have every reason to believe that the introduction of this Russian wheat will be exceedingly valuable to the Dominion. We also obtained seed of many other varieties of wheat, barley, oats and potatoes, to be tested at the Central Experimental Farm. A large part of the farm was in rather rough condition at the outset. Much of it had been occupied by tenants for a number of years, and there was a large amount of stone on the surface. There was also some forty acres of swamp on the back part of it. The greater wart of the land was good, but required much work to get it into propor order. The removal of stones and internal fences was promptly undertaken, but by the time the land was got in order it was too late to do very much in the way of seeding.

\section{THIS SEASON'S TESTS.}

However, we have tested during the year quite a number of varieties of grain, among the rest 67 varieties of spring wheat, 31 of barley, 60 of oats, and 246 varieties of potatoes. On account of the hot, dry season being unfavorable for grain and potatoes, we have not obtained such good results as we otherwise should have done; but we have succeeded with a considerable number of varieties in obtaining very fair crops, and shall have from the small quantities begun with a sufficiency of seed to test those varieties under more favorable conditions another year.

\section{CLEARING, DRAINING AND BUILDING.}

There were on the Experimental Farm about 140 acres of land which was covered with pine stumps,amongst which there was a strong second growth of poplar and birch. This land has all been reclaimed by blowing up the stumps with dynamite, and rooting up the poplars, and it is all now ploughed and ready for cultivation. The farm has also been fonced and got into such shape that good results may be expected another year. There will be room enough in the area acquired-46j acres-to test all the varieties of produce to which re- 
furence has been made. The forty acres of swamp have been drained, and barns and stables are being erected for the acommodation of stock and horses. These buildings will bo completed in the course of a few weeks and will be large enough to accommodate about 75 bead of stock and a sufficient number of horses for the farm work, so that the foundation will be laid for operations in this direction another year. Dwellings are being erected also for the superintendents of the different departments, so that they can reside on the place and devote their whole time to the work. Plans have been prepared for a laboratory and a museum of the products of the farms for the benefit and instruction of visiting farmers, and offices will bo provided in the same building for the transaction of business.

\section{A REPRESENTATIVE OLIMATE.}

Ottawa may be said to be fairly representative in climate of a large area in the two Provinces of Ontario and Quebec; hence it is important to determine there not only what cereals and farm crops can be raised, but also what varieties of fruit can be produced, as fruit trees are generally taken by strangers.and visitors as an indi. cation of the character of the climate prevailing in the district, and are appreciated much more readily than crops of grain or roots would be. It is also important that the people in ievery district should be able to grow their own fruit, and therebyiadd not only to the attractiveness of their homes and surroundings, but also to the profits attending farm work. The impression has prevailed that the Ottawa district is not a good fruit-growingl'section; but I think it is quite possible and wholly probable that varieties of fruit can be introduced which will be found exceedingly useful and very profitable to cultivate. On the farm there have been planted, under the direction of the horticulturist, W. W. Hilborn, 1,000 apple trees, including 297 different varieties; 298 pears, of 114 varieties; 197 plums, of 72 varieties; 11 varieties of peaches, $4 \%$ of apricots, and 27 of crab apples. In small fruits also a great deal has been done. The planting includes 127 varieties of grapes, 90 of strawberries, 37 of raspberries, 21 of blackberries, and 16 of curr ants, besides which 
there are a number of new seedlings being tested. We do not expect or hope that all those varieties will be useful, but it is expected. that among them will be found some of superior excellence which will be adapted to the needs of the community here, as well as some fitted equally well for other climates of the Dominion. As to the botanical and entomological departments of the work, the officer in charge of them (Mr. Fletcher) is here and will speak for himself. A skilful chemist, Mr. F. T. Shutt, has bəen appointed, who will undertake the analysis of soils, crops, grasses, \&c.; also the analysis of milk from the different breeds of cattle, and such other chemical work as may be needed.

\section{POULTRY DEPARTMENT.}

It is also proposed to establish a poultry department. The development of the poultry interest in Canada has been very rapid, and the exports of poultry products now foot up a sum that is astonishing. They exceed in amount our exports of horses, and it has become a subject of such importance that it is thought necessary that some experiments in that line should be carried on to determine the rela. tive value of the different breeds and crosses for the production of eggs and dressed poultry for the markets. Enough has becn said, I hope, to show the importance of this great undertaking for the benefit and advancement of agriculture, in which both the Premier and the Minister of Agriculture take so warm an interest. No effort will be spared to make these institutions a success, and they will, I trust, stand as permanent proofs of the wisdom and forethought of our great statesmen, the Premier, and the Hon. the Minister of Agriculture, and confer lasting benefits on the farmers of Canada. (Applause.)

Mr. Fouell-I would like to ask Prof. Saunders if the soil absorbs the nitrogen contained in the second growth of clover that is allowed to remain on the ground and rot.

Prof. Saunders-I should scarcely expect that that portion of the nitrogen which is contained in the foliage of the plant would be $2 \frac{1}{2}$ 
so well preserved to the soil when it is allowed to remain on the surface, as when ploughed under; but the analjsis of the roots of clover shows that a much larger proportion of nitrogen exists in the roots than in the leaves; so that the fact of the clover growing there would enrich the soil, and some portion of the nitrogen in the leaves, by the process of decay, would erentually become incorporated with the soil and act as a furtilizer.

Mr. Darling-At what state in the growth of the plant would the most benofit be dorived by ploughing it under?

Prof. Saunders-Plants are always richest in their constituents about the flowering period. It might sometimes bo considered too great a sacrifice of the crop to plough it under when fit to cut for hay; but that is the time when the ploughing of it in would be of the greatest benefit to the soil.

Mr. Moffat-Have you yet undertaken any experiments to determine the best breeds of cattle for dairying purposes in Canada?

Prof. Saunders-Not yet; we are waiting until the necessary buildings are put up, when it is intended to undertake, as fast as practicable, those different departments of work. Those which seem to the Minister to be most pressing will, of course, be the first undertaken. It will be impossible to undertake every department at the outset, as there are five different farms to be established and organized.

\section{INSECT AND PLANT PARASITES.}

Mr. Fletcher was next called upon to address the Institute. $\mathrm{He}$ said: It is a great pleasure to one who makes a special study of any particular branch of knowledge, which he considers is of use to the community at large, to have the privilege of addressing such a meeting as this. Those who take the trouble to attend these meetings are the men who take the most interest in the work with which such institutes as yours are concerned, and, therefore, though the at. tendance may sometimes be small it must always be conceded that 
those who come represent the best class of your members and are the ones who will derive most benefit from such meetings. Professor Saunders has told you that he hoped to get some information from you that would be useful in his work at the Experimental Farm. This is no less the case with me in the departments which have been placed under my charge at Ottawa, and I hope I may be able to show you that it will be to your advantage to assist me. He has told you that I am the Entomologist and Botanist of the institution. It is true this is my title, and these are fice sounding words, but they are not easily enough understood by everybody, so when I am asked what my work is, I answer-to study injurious? insects and plants and the best remedies to keep them down. As you all know, a very large proportion of your crops is taken away from you, year by year, by insects; there is also a large amount destroyed annually by injurious plants.

\section{THE ENTOMOLOGIST AND BOTANIST.}

I will now, with your permission, give you some idea of the work it is proposed to carry out in my departments at the Central Experimental Farm at Ottawa. There are two kinds of injuries to crops, which as Entomologist and Botanist I shall have to consider, namely, those diseases of plants due to insects and those due to vegetable parasites. I believe it is possible that in relation to them the work of the division may be made of great use to the country at large. I have undertaken it with a great deal of enthusiasm, believing that much good will come of it, and I shall do my best to make this branch of our experimental work succeed; but I shall look to the farmers for assistunce. In a vast territory like Canada it is impossible that any one man can take in the whole field of, observation aloue. It is possible, however, if that one man gives all his attention to the work and he is assisted by correspondents in the different provinces, that his studies may bring about results of general benefit to the whole Dominion. It is in the hands of every farmer who is a practical observer and who grows his crops with all his mental energies directed towards their improvement, to aid 
by sending in the result of his observations. It has been said that the ordinary farmer is unable to assist in these scientific studies. This is not the case. A very small fact is of value if it is the result of what the farmer has actually seen take place on his farm, a true record of that one fact is of itself important, and when added to the observations of others may fill a missing link in our knowledge on any given subject, and is, therefore, of great use to science, for science is simply a word that is used for " the best knowledge." It is a word that is apt to frighten people, but it is only the Latin word for knowing or knowledge. Then if you will help by sending any small facts that come under your notice they will be an assistance to other farmers all over the country, for they will be incorporated in reports and will be distributed far and wide all over the Dominion. Arrangements have bcen made by which this intercourse can be facilitated with the least possible trouble and expense to farmers. When crops show signs of disease it is of great importance to discover the nature of the injuries and see whether they are of insect or vegetable origin. If anyone finds his crops attacked in in any way, and he will send specimens of the plants attacked - this can be done free of postage-in most cases information respecting the trouble will bə obtainable from the Experimental Farm at Ottawa. Efforts will be made to have this institution recognized as a

\section{BUREAU OF INFORMATION}

to which any farmer who desires information concerning agricultural matters can write. It is hardly likely that the Director will have time to attend to all these himself; but be will hand the letter to whoever the officer may be in charge of the special depertment inquired into, and the desire of the Director is, as he has told you, that farmers should not hesitate to write to him for any information whatever concerning their farming operations. Those onquiries requiring information concerning insects or plants, will come to me, and I shall attend to them at once, and shall endeavor to give you as much information as possible. As well as letters, you can send samples to Ottawa to our headquarters to be examined and reported 
upon free of charge. This is an important advantage to you. Froquently

\section{FARMERS LIVING AT A DISTANCE}

from town have no postage stamps on hand, and they may say "I will let this stand until I go to town when I can take it in and have it posted," but in these cases it is frequently forgotten until too late. They need not delay on that account; they have only to take their samples to the post-office in proper packages, throw them in, and they will be at once forwarded free of postage, and the answer will come back as quickly as possible. There is no doubt at all that a report on the different kinds of injuries from insects and parasitic plants is very advantageous to all farmers to read and study. If a farmer knows that a certain injury is going on in one part of the country-either the attack of an insect or a fungous disease, he will keep his eje open to ascertain what remedy is discovered, in case he receives a visit from the unwelcome stranger; for although ail these studies are of great interest in themselves they are of very little use to the country if we do not find remedies for the attacks. This is our chief aim. We hope by getting men who devote all their time to these subjects, study hard and work them out from the begining, to find remedies for all these diseases. There are a great many for which remedies have not been found; but on the other hand a good deal of work has been done by scientific men with good results, although they do not always get the credit of it. What farmer, when he bays five cents' worth of Paris green and saves his potato crop, thinks of the men who spent jears in hunting for a sure and cheap remedy for killing the potato bugs? Yet we could not attempt to-day to grow a crop of potatoes in sone parts of Canada without Paris green any more than we could without manure.

\section{INJURIOUS INSECTS.}

Let me now say a few words with regard to the injuries committed every year by insects. These are so enormous and so well known that probably no one here will challenge the propriety of the Government having appointed someone to devote his whole time 
to the study of the best means of keeping their ravages within bounds. I will give you a few figures which have been carefully verified as to the extent to which these injuries may reach. In the first place, it may be stated generally that ten per cent. of all crops is annually destroyed by insects. Frequently, however, this proportion is far exceeded. In 1882 one of several kinds of insects which attack the hop in England reduced the crop by the value of $\$ 13,000,000$. In the 1874 report of the United States Commissioner of Agriculture it is stated that the loss on the cotton crop by insects is about $\$ 25,000,000$ a year. In 1873 the money value of wheat and corn destroyed in the State of Illinois by one insect called the chinch bag was $\$ 73,000,000$. No wonder then that there is consternation at the present time in that State where this insect has again appeared in numbers. To come nearer home, in 1854 the wheat midge destroyed in Canada $8,000,000$ bushels of wheat. It becomes a necessity then that someone should be appointed to in. vestigate these subjects and try if possible to find practical remedies which farmers can apply for themselves. I have stated that ten per cent. of all crops is destroyed by these pests. I believe I might without exaggeration say twice this amount, but it is better to be under than beyond the mark. You may say, This is all very fine your teliing us about these losses by insects-have you any remedy - can you give us any hope of relief from their ravages? I answer, yes; certainly I can if jou will help me. I believe that all these insects, when their life-histories are studied out and their habits ascertained, can be kept down in a very large degree. Let me give you one instance which I bave frequently cited before, because it is taken from the practical work of practical men. If you will take the trouble to look up the last census you will see that the revenue from one small crop-the clover.seed crop-was half a million dollars at the time the census was taken. Three years ago the revenue from that crop was reduced to nothing. There was not a grain of clover-seed exported, and why? Because a little fly, so small that it would lie on the head of a pin, had gradually worked its way up from the United States and had got into our clover fields. 
and attacked them so severely that there was no crop to reap. People began to give up growing clover-seed. Finally, the farmers put their heads together and consulted with those who studied insects, and said, "here is a great trouble coming upon us, and we must have some remedy." "Well," said the entomologists, "let us look into the matter and find out what is the nature of the insect, and what is its life-history, and then perhaps we can find a remedy." Now I will mention here what perhaps some of you know : before insects attain their perfect development they pass through four stages. When we talk of the borer in the apple tree to a man who knows nothing of the lives of insects and say, "you must put something obnoxious on the bark of your tree at the time the eggs are laid to keep the beetle away; "such a one would say, "this is not a beotle, it is a soft grub." This is true; but it was not always a soft grub, nor will it always remain so.

All insects go through four distinct stages of existence: First, there is the little egg, which is laid by the mother insect; this hatches into a soft, grub-like, active insect which passes its life eating, until it is full grown; from this it changes into what wo call the chrysalis state, in which it has generally the limbs of the perfect insect apparent, but in most orders of insects lies quiet and cannot use them; from this chrysalis, after a time, emercyes the perfect insect. Now, let us apply this life-history to the clover-seed midge The farmer wanted to know how to stop the ravages of the midge. So he set to work to find out its life-history. He examined the heads of clover seeds, rubbed them up in his hands, and found that the pod which should have held the clover seed was all right in appearance; but on opening it, instead of a seed, there was a little red grub inside. How did it get there? I will tell you: Let us start in the middle of June when we shall find the grub in the seed. We put the head of seed into a glass jar and watch to seo what happens. Towards the end of the month-remember that date-the little grub works its way out of the clover and falls to the ground; here it burrows down below the surface and remains there for some weeks. The farmer who knows nothing of insects cuts 
his clover about the beginning of July, and is surprised to find no seed. He thinks, however, he may have better luck with the second crop; but just about the time this is in flower the little grabs which had gone into the ground in June have matured, and the perfect insects-tiny midges-appear. These begin operations at once, and the females lay a single egg in each clover flower, which hatches, and the young worm works its way down into the pod, and before it is full grown has consumed the whole contents. Now, how are we to stop it? Simply by getting the clover off the fields before the end of June. It was found by experience that by cutting the clover byfore the first brood came to maturity,or tarning in cattle to feed on it, a large number of these insects were destroyed, and there were consequently few left to lay egga in the second crop. So the farmers in the west where they grow clover-søed, now reap only one crop where they formerly grew two in a season. They either cat their clover soon after the middle of June or turn in their cattle to eat it so that it may not stand in the fields till the end of the month; because if they waited until then, the little insects would have come out of the clover and gone into the ground, whence they would emerge in due time to attack the next crop. By persevering in this course the farmers have gradually thinned out this pest, and will, I believe, eventually get rid of it altogether. Another benefit which has come from the study of entomologists must be mentioned, namely, the use of Paris green as an insecticide. This was not discovered by accident; it was the result of direct study in seeking for a remedy for the potato bug. During the last fow years

\section{The potato BUG}

has increased so much that we now have to use this remedy as a matter of course. It is not known by all farmers that the remedy is perfectly harmless when applied to this crop. I make this statement because there is in some sections a wrong impression about it-it is stated that the potatoes absorb it; now, it is utterly impossible to poison the potatoes by putting arsenic, which is the poisonous principle of Paris green, on the soil. The potato tuber is merely 
a receiver of food for the nourishment of young plants, which are represented by the eyes. It is not a root, but a swelling in an underground stem, and the eyes are buds. It is provided by nature as a reservoir of special food for the young plants in the following year. Very little of this nourishment came in through the roots. The largest amount of substance, the starch, that is stored up in the tuber of the potato, was taken in an elementary condition through the leaves. It is perfectly absurd then to talk of arsenic being taken up in the roots and stored in the tuber of the potato plant, Spraying with a weak mixture (only two ounces in 40 gallons of water) of this material has been discovered to be the best remedy for the injurious codling moth which destroys our apples. This insect is so injurious that in some years it destroys as much as 80 per cent. of the whole crop. By the use of this remedy it has been found that $7 \tilde{j}$ per cent. of the whole crop can be saved every year. I believe that if it were applied generally over large areas we could eventually get rid of the codling moth altogether. More men are studying this economic aspect of insect life year by year, and we are gradually becoming able to keep in check most of the worst insect enemies with which the farmer has to contend. But there are still a great many of these pests which are doing an enormous amount of injury, and for which we have not yet found practicable remedies. These it will be my duty to study for this purpose.

There is one of these which attacks the wheat crop, cencerning which I wish to enquire particularly. It is called the wheat bulb worm, and has appeared lately in this district. The indications of its attack is probably known in your district as "silrer top." The appearance of the disease is this. The young ear of wheat turns white prematurely before the rest of the crop is ripe, and when you pluck it you will find there are no grains in it. If you will examine it carefully, you will find that there is a very small transparent maggot inside the stem above the top joint. You will notice at once these dead ears of wheat in fields where this pest is at work. I fear, too, there is now no doubt but that it has been increasing in num - 
bers during the last year or two. It is a very difficult insect to combat, from the fact that it matures and leaves the wheat stem before the main crop is fit to cut; consequently it has escaped and is ready to lay its eggs for the next crop. There is a littlo gap in our knowledge of the life-history of this insect. We know that it passes through two different circles of life. First of all it exists in the first brood in the straw of standing wheat; then there is a long gap botween that time, from about the beginning of July until September, during which we know nothing of its habits, but we find that in September the perfect fly appears again and lays its eggs on the sprouting fall wheat, and the little maggots eat their way down to the base of the stem of wheat, from which it is called the "wheat bulb worm," and remain there all winter in the root of the wheat, just in the same way as the insect which you all know too well, the "Hessian fly," which alko pzsses the winter in the root of the wheat. There is then a gap between the summer and the autumn broods, which I want to find out something about. Very

\section{FEW INSECTS ARE LONG LIVED.}

This inseet has a long life for so small a fly-not a quarter of an inch in length. Some that I enclosed in glass jars lived for three weeks without any food at all. This proves that it can live a long time, but it is hardly possible that it can live in the winged state for two or three months in summer. We know that the maggot lives through the winter in the wheat plant, and I think it is possible that it attacks some of our wild grasses and that an intermediate brood lives in them during the period of which we have no trace of its habits. This is one of the pests for which we are ansious to find a remedy, and in which you can all help me. One of my correspondents reported that one in every thirty heads of his wheat was destroyed by this insect last summer. Now there are certain broad general principles for your guidance when you find your crops attacked, and these are founded upon very simple rules. In the first place if you examine a large number of different insects you will find they may all bo divided into two largo divisions by 
the nature of their mcuth parts. In one these will be found to consist chiefly of a pair of jaws with which they tear the substance of their food; in the other there is, instead, a tube by means of which the insects suck up their food in the shape of liquids. For the first class it is apparent that any poisonous substance placed on the food will be consumed with it and the insects destroyed. It is, then, merely a matter of getting some material not injurious to the plant, but which will kill the insects preying upon it. Such we have in various compounds of arsenic, as Paris green and London purple. For the other class, which could push their beaks through the poison and then suck out the juices from the plant beneath, we must have recourse to other methods, such as those which will kill by coming into contact with the bodies of the insects or by virtue of some noxious rolatile principle. One of these we have in Persian insect powder. Of all the numerous insects which attack vegetation, and some plants are attacked by as many as 200 different kinds, I suppose there is not one for which a remedy of some sort could not be devised; but the trouble is we must find remedies which are practicable, such as while they attain the object aimed at are yet of such a character as not to lay us open to the accusation that the remedy is worse than the disease. There are

THRE SIMPLE RULES FOR THE APPLICATION OF ALL INSECT REMEDIES.

First, they must be effectual; secondly, they must be economical; thirdly, they must be simple. Most of the substances used are direct poisons and many of them are costly. The remedies suggested must be devised with special regard to these points or they will be useless, and simplicity is a most important feature, for if they require much care in their application or preparation, not only may they not be used in the right proportions, but they will probably not be used at all. Remedies may be divided into three classes; first and most important-1, agricultural, by which is meant such methods as, a judicions rotation of crops; planting and reaping at a different time to that usually adopted; the selection of seed less liable to attack; the use of special fertilizors and the 
alluring to a more attractive food plant. 2. Active, by which poisonous materials are used to destroy insects, and 3. Preventive, by which they are deterred from approaching the plants wished to be protected. This is most easily accomplished by the use of obnoxious materials to prevent the females from laying their eggs where the young grubs can do mischief. Alkaline washes on trees and carbolic washes for the protection of root crops come under this head. For further details on this subject, I will request any of you who wish to obtain them to write to me at Ottawa.

\section{PARASITIC PLANTS.}

The large annual loss to crops is not, however, entirely due to insects, there are also microscopic fungous diseases which destroy crops. Perhaps one of the most injurions of 'these on record was one that attacked the coffee crop of Ceylon. In the ten years, 1869 to $1878, \$ 60,000,000$ of injury was done by this one variety of parasitic fungus. We also know that our wheat is apt to be attacked by "rust" and "smut." These again are parasitic fangi, and although we have not $y$ et found any practical remedy for rust I am in hopes we may be able to do so. For smut, however, we have a very easily applied remedy which is efficacions. It has been known for upwards of 200 years that by washing seed wheat with a solution of bluestone the plants from seed so treated are more exempt from the attacks of this low form of vegetable life than wheat sown without such treatment. In England the farmers seldom sow wheat withoui first washing it with bluestone, and the coneeqnence is that smut is not at all prevalent in the wheat fields of England. Now, what steps should be taken by farmers when they find their crops attacked by disease? First of all they should examine them carefully to find out whether it is an attack of a fungus or of an insect. For fungi it is more difficalt to find a remedy that can be applied at once, but steps can be taken to prevent in the folluwing year a repetition of the evil. No sane person will reside in a locality which he knows is infested by any contagious disease. In the same way it is very foolish for us to plant good seed in a field in which we 
know that the summer before the crop had been destroyed by some disease. Besides the weeds which give so much trouble there are some other injurious plants which it is possible you may not some of you recognize as plants. For instance, it does not occur to many farmers when they see "rust" and "smut" on their wheat, or the "black spot" on their apples, that these are plants. As a matter of fact, however, they are just as much plants as those on which they are found; but they are of quite a different nature, for they are parasites and derive their nourishment from the larger plants upon which they grow. All their parts are exceedingly small, and it is necessary to examine them with the aid of powerful magnifying glasses before we can understand the secrets of their lives. The smutty ears and the rusty discoloured spots on the leaves and straw of wheat are not the whole plants; but merely the fruil, con. sisting of collections of innumerable seeds-or, as they are called when speaking of fungous plants, spores-each one of which is so small as to be invisible to the naked eye, but which, nevertheless, is capable of infecting a whole wheat plant should it come in cortact with its tissues-I have said that what we see is only the fruit. You may say "where, then, are the other parts of these mysterious plants ?" I will tell you. In the case of the "smut" the spore lies in the ground or is carried there upon the seed, and when the soung wheat plant begins to grow this enemy forces its roots into the tissues and soon permeates the whole plant. By the time it has found its way up to the ears it is mature and ready to produce its fruit in the shape of the black, sooty powder, the appearance of which you all know so well. The poor wheat plant all this time has been robbed of its nourishment by this parasite living inside its tissues, and is unable to produce its seed. The spores of the fungous which produce "rust" do not act quite in the same way, but are carried by the wind and settle on the leaves or stem, and there send out their roots, which find an enterance between the cells and spread out in all directions, sacking up the nourishment and strength which should have gone to produce the grain of the wheat plant. The result, however, is nearly the same, the weakened straw is unable 
to carry up nourishment sufficient for the grain to properly fill out, and there is, consequently, a great deficioney in the amount of seed produced. There are, however, certain preventive remedies which can always be applied, the best of which are the judicious rotation of crops and the choice of seed of varieties which are known to be free from attack. On well cultivated farms you do not continue growing the same crops on the same fields year after year. In Canada farmers have ample means of getting information; you take agricultural papers and read them. You use improved methods of rotation of crops, thus securing not only the advantage of the con. stituents of most use to each kind of crop which is accumulated year by year from the manure, only certain parts of which are used by each crop, but you are also exempt to a large degree from the $=0$ destructive diseases of which I am speaking. For instance, the wheat is attacked by rust or smut, and these diseases are allowed to come to maturity and the spores are left in the soil ready to attack the next crop of a similar nature if sown; bat if by rotation of crops you have two or three other kinds of crops following it, the probabilities are that the spores become exhausted and cannot attack the same crop when it is its turn to be sown again. The chief remedies to be applied then for fungous diseases must be preventive, because we know very little about them. I hope in a few years to have studied some of them out, and then may bo in a position to prescribe remedios.

\section{A BOTANICAL GARDEN.}

There will be at the Experimental Farm at Ottawa a botanical garden and arboretum. An area of sixty-five acres has boen set apart upon which trees and plants of economic value will be grown and tested. Plants from other parts of Canada, not growing here indigenously, will bo cultivated to see if we can make use of them in this district. Plants from other countries will also be tried to see if we cannot incroase the number of useful plants now grown in Canada. As an instance of what may be done in this line, I will mention the Cinchona tree from which quinine bark is taken. For 
years after its discovery. it was supposed that this would only grow in its native forests of South America, but it is now cultivated ozer the greater part of the tropical regions of the world, and supplies the product called quinine, which is one of the most valuable medicines known, and, in all tropical climates, is a necessity in the treatment and prevention of malarial fevers. Why should wo not be able to introduce into Canada useful trees and plants which we have not now, but for which we have plenty of room. At the Central Farm last season we cultivated some of the fodder plants which are not grown yet in Canada - one of them from the East called "Gram," belonging to the same natural order as the vetches and clover, gives promise of succeeding well here, and, should it do so, is a new fodder plant which may be of great value to farmors.

\section{THE QUESTION OF FOREST TREES}

is one of greater importance than farmers are generally inclined to believe. They cultivate their fields for wheat and other crope, but they do not think much about the trees, though the corsumption of wood from year to year for different purposes is so onormous that I am afraid to mention the figures. In the United States a report has lately been pre pared by Prof. Fernow, the Chief of the Division of Forestry, which shows that the amount of wood used annually for different purposes, for the construction and repairing of railways and bridges, etc., is something appalling. The supply of wood in our country is being so reduced by lumbering operations, settlement and forest fires, that it is necessary in all parts of Canada to begin at once to renew the supply by tree planting. Year by year the farmers in new districts destroy enormous quantities of timber in clearing their tarms, but in a fow years they will have to seek for this material at a great distance. This makes it all the more necessary for farmers to undertake the planting of trees on their farms, not only to cover up this loss, but also as windbreaks and shelters for cattle, and it is very important for them to know beforehand in what way they can do so to the greatest pjssible benefit. The farmor is not always posted on the most advantageous way of planting. Some will be surprised to hear that with many 
trees it is more advantageous to grow them from the seed than to transplant them of considerable size from the forest. Again some of our îorest trees are very much morevaluable than othera, and there is much yet to be learned with regard to the best trees to grow on certain soils and in special localities. Extensive experiments will be made in this direction, all of which will be of great use, so that all efforts may be directed in a useful and methodical manner. I will call your attention to two of our most useful and beautiful native trees - the black walnut and the white ash. The first of these is found wild in Canada, only within very restricted limits, and it is supposed by some to grow only in places where it will obtain a considerable degree of heat. As a matter of fact, it has been ascertained that this tree will stand a much greater degree of cold, and will tbrive over a much wider area than was at first supposed. At Ottawa it proved to be the second quickest growing Canadian tree; it has been planted in Quebec and has succeeded remarkably well. It is one of the most valuable of our native woods, and is also an extremely rapid growing tree; and although there have appeared during the last few years fabulous statements-which bave done a great deal of harm-as to what returns can be had from growing walnuts, there is no doubt that by judicious planting of this tree a quick return for the money can be obtained. Another tree of special value is the white ash. This tree is useful for certain purposes at a moderate size, it grows easily and does not take up much room. When farmers are planting trees they will find it advantageous to know beforehand those which will give the quickest returns and those which are the most valuable for timber. As I have said, all such exporiments as these will bo tried carefully at the Central Experimental Farm. Large numbers of difforent trees will be grown from seed for trial in different parts of the country, in order to ascertain where they do best, and what kinds can be grown to the greatest advantage in certain districts. Efforts will also be made to improve the different kinds of grains, fruits and other products. It frequently happens that some varieties have qualities not possessed by others, and by hybridising or crossing these it is sometimes pos- 
sible to produce a new variety with all the good qualities of its parents consolidated. It is not wise to continue all the time with old varieties which we know will succeed; but with such an institu. tion as

\section{THE EXPERIMENTAL FARM}

we shall be able to risk failure sometimes in the hope of getting something new and useful, and I understand this is one of the objects for which the farm was established by the Government. No farmer can afford to run the risk of losing a whole year's crop in trying new experiments. The Government by establishing this institution has virtually shown its determination to help the farmers as much as possible. It is not right in such a new country as Canada for individual farmers to have to risk large sums of money in these experiments, important, nay necessary, as they are. So the Government steps in and says, "I will have them done for you and you shall have the benefit of the results." I believe that the results obtained under the present direction will be highly practical; but the work will not end here, it will not be the obtaining of results alone, these will be published periodically as bulletins written in such a way as to be intelligible to all who may read them, which will be distributed brosdcast all over the country.

Mr. Serson expressed himself as being very much pleased with the address. He would like to hear Mr. Fletcher's opinion whether the weather had not something to do with rust. He thought that when warm, moist weather prevailed it was more favorable for the production of rust. He would like to know whether in a dry season a clean crop of wheat or oats might not be grown on a field in which in the previous year with a warm, moist summer the crop had been badly attacked by rust.

Mr. Fletcher said there was no doubt that under certain atmospheric conditions all fungous plants were developed more rapidly than at other times; at the same time they could not come into existence spontaneously, they must all come from spores or seeds. One season you may have planted in such a dry time that the $3 \frac{1}{2}$ 
spores do not get a start. You celtainly might possibly grow even on the same field where a crop had been badly attacked by rust in the previous year, but under different atmospheric conditions, a crop of wheat that might not be affected; at the same time, as a preventive remedy, it would be far better to grow on that field some other crop, clover or roots for instance, than to grow wheat again the following season.

Mr. Serson said he had often seen in a field of wheat rich spots where the wheat would be more affected with rust than on the poorer parts.

Mr. Fletcher said very vigorous growing varieties of wheat would sometimes suffer more from rust than others. Last jear, beforo the Agricultural Committee, the experience of different members of Parliament was given, and the report would be published next session. He had no doubt Mr. Jamieson would be glad to furnish his constituents who wished it with copies of this report. Thero seemed to be no definite rule that could be laid down with regard to rust on wheat, experience in different localities was so different. One man would complain that a poor or weakly variety was attacked worst by rust, while another would say that a frec-growing variety was most attacked. One gentleman went so far as to say that all quick growing varieties were liable to rust.

Mr. McKinlay said he had noticed on the coast of Newfoundland that if a foggy morning occurred at a certain period of the year be always found his wheat rusted.

Mr. Fletcher said that in England it was probable that there was bardly a crop of wheat grown which had not been, during somo time of its growth, subjected to foggy weather, yet there were many crops of wheat raised there without rust. It might be that if the plant were in an unhealthy condition it would be more susceptible to disease in figgy weather. As a matter of fact this rust on cereals is more widespread than any other vegetable disease known.

An_interesting discussion followed, which it was impossible to 
report owing to the darkness of the roum. The moeting closed with the election of officers for the ensuing year.

The accompanying letter of Colonel RAvenhil, R.A., Inspector and Purchaser of R.A. horses, signed also by Colonel Phiclips and Thomas Matthews, B. 1st Class, Royal Horse Guards, on the subject of the conditions afforded by Canada for the supply of horses for the Cavalry service in England, and also an addross by Colonel Ravenhil to the Horse Breeders of Great Britain, are published by direction of the Minister of Agriculture, in view of the interest and importance of the information contained in them, in relation to horse breeding in Canada, and particularly with a view to building up an important export trale for the Dominion.

Departient of Agriculture,

Otтawa, 16th March, 1887.

\section{LETTER RESPECTING HORSES AND HORSE BREEDING I $\mathrm{N}$ C A N A A.}

\section{Royal Artilleby, Remount Establishment, Woolwich, 27th December, 1886.}

SIR,-In compliance with the request contained in your departmental letter of the 6 th October last, I have the honour to forward the following remarks which have occurred to the officers of the British War Office Commission respecting the horses in Canada.

1. The result of the horse trade of the Dominion is not an easy matter to arrive at, for there are no advertised horse or cattle fairs, or other organized live stock markets, where collections of horses and animals are to be found on sale, as is the case in all other horse producing countries. Even justacross the border in the United States, the horse rearing localities have their periodical court days, 
when, according to the season of the year, a considerable number, or smaller quantity of animals are offered on $\varepsilon a l e$; and it would be much to the benefit of the Canadian breeders if some similar plan could be introduced by co-speration throughout districts, on fixed market or exhibition days, as a means of bringing the producer and purchaser together in greater numbers, with corrosponding advantages for both sides, thus upsetting the existing monopoly. The whole horse and cattle trade of Canada is at present in the hands of Americans and a few other dealers, with some amateur horsemen in each district, who regulate the rates, rule the breeders in their respective districts and give whatever prices they choose, which are low, and in the case of the American dealers are so small that it repays them to take horses across the frontier to the extent of 11,000 last year, and yet be able to pay an import duty on their entering the States of 20 per cent. on the declared value of each animal.

2. The ignorance and innocence of the breeders and owners as to the comparative value of their animals may here be instanced. It is stated that in some places where local or other exhibitions of stock were being held, the agricultural authorities had most generously got together subscriptions to help our work and offered considerable money prizes at the autumn shows for horees best fitted for British military purposes, when such indifferent animals were exhibited for these prizes that it was not possible for us to award any premiums or even purchase anything; in other parts of the same town where we had appointed, good and excellent horses wore collected for us to see, many of which we purchased and in one or two cases had the greatest difficulty to induce the owners to enter their animals so that we might award them a prize and thus give what amounted to a higher price for their horses.

In this matter the people require education, and time to understand the system of dealing with their stock.

3. It may be desirable here to remark that if the opinions generally of those men in Canada who are, at present, interested in or 
connected with the horse trade, were asked, they might be found antagonistic to these proposals as upsetting their monopoly, and it is believed that the Canadian farmer is so slow to act or observe that he might not at first appreciate what, if once introduced and carried out, would prove to be for his material advantage.

4. In the present state of the horse trade of the Dominion, no English or European dealer (where after all the great market is to be looked for) could afford the time, or expense, of moving about the country along great distances, and only boing able to purchase a very limited number of good, unblemished, sound animals.

5. The price of a horse all over the world is fictitious, uncertain, and dependent on what his manners are like, what he is fitted for, his size, breeding, action, colour, appearance and power, \&c., whether he is for riding or draught, whether a good hunter or an indifferent hack, whether he is blemished or not, and to ensure a good price be must be sound and otherwiso perfect, and any departure from these may depreciate his value, whereas the price of a bullock is not so regulated, it becomes a law of supply and demand, and is de pendent on the amount of human sustenance required, whether meat or milk. Many of the horses of Canada are very good, and if a cuoperating market could be introduced, buyers from Europe, giving good prices for good animals, would assemble, and the breoders would get higher prices.

6. We think it right you should be informed that during our visit to the Dominion, which occupied 167 days, we travelled 14,755 miles, we examined $7,67 \pm$ horses, of which we registered, to look at a second time, 1,025, with the result that we were only able to purchase for the Government 83 horses.

7. The prices of the whole of these were very reasonable and moderate, and it was no question of money in the majority of cases which prevented our purchasing in larger numbers.

We found that the great proportion of horses met with of the size and sort suitable for British military purposes were unsound or 
blemished, from the farmers overworking their stock whon too young, thas breaking down the young ones before they have developed into horses.

The attention of breeders and farmers cannot be too strongly drawn to this serious deterioration, and when the mares come to bo brod from, their ills are transmitted to their young stock.

8. The number of faulty and unsound stallions in districts is also great, and creating much harm.

9. A malformation in the Canadian horses which might advantageously be brought to the notice of breeders is that their quarters are short and very drooping, a sorious defect in a military horse. Indeed we had to reject as unsuitable a considerable proportion on this account; this is not only a great dissight, but where a mounted soldier has to carry a kit on his horse's back it amounts to an insuperable objection; it has arisen from the too extensive use of the American trotter for stud purposes, this defect being ver'y apparent in that horse. This is an additional reason for the $m$ ore continuous introduction of the English T. B. or such horses which are very straight in their backs and quarters, with tail set on high.

10. Then, of course, the American dealers do not take away the worst of the horses, and purchase many very valuable mares, leaving in the Dominion the unsound malformed stock to be bred from, which, put to unsuitable and in many instances unsound stallions, transmit to their progeny their various parental ills, for unsoundness in the horse is as surely hereditary as consumption, cancer, scrofula, general weakness or unkoundness is among the human race.

11. It thus becomes a question whether the Canadian Government cannot afford some direct help to this very valuable industry, so neodful and remunerative in time of peace, so requisite and indispensable in time of war; and it is suggested, on somewhat similar grounds as has been successfully established in Australia, there should be an inspector of horse breeding operations in Canada. 
12. It is not desirable to interfere with free trade in horses or in any way to place a prohibition or prohibitive duty on the sale or export of mares, but on the other hand a considerable number of remunerative premiums might be offered by the Government in districts (for the next ten years) for brood mares of a certain size, weight and standard, which must be laid down, with foals at foot, say $\$ 20$ per head for the ten best, $\$ 12$ per head for the second ten mares, at each district show, with still larger premiums for stallions, which would have also to be of a fixed weight, standard and quality, thue inducing farmers to keep their best stock in the country.

13. Owing to the extended rail communication in the Dominion, farmers have not now so far to travel with their light, quick going horses along roads as they had twenty years ago, and the large cities and towns springing up have created a demand for heavier horses; thus breeders have been turning their attention more to the class of Clydesdale, Shire and larger horses, and have ceased to breed so many as formerly of the lighter, better bred, general purpose horse which is that required for army purposes. Again, the people of Canada are not a riding race; you never see a boy riding a borse to plough, nor a man on the back of an animal going to the village forge. All travel on wheels in summer or hitch their horses to sleighs in the winter time. The only riding horses made use of are purely those for pleasure with the limited number of hunt clubs and the still smaller quantities of people who, independent of those who hunt, take horse exercise in and about the larger towns, together with such horses as may be used in the yoemanry and other mounted corps.

14. The consequence is that it is quite the exception when a horse with lengthy rein and quarters, good withers and lengthy sloping shoulders, suitable for riding, is met with, this strain being only procurable by a judicious admixture of the T. B. horse which should be liberally subsidized by Government with extensive premiums for all that are sound, of good size, bone, colour and action such as will provide the requirements of the Western market. 
(The importation into England alone is over 17,000 horses annually, all from foreign sources, so that this trade is worthy of consideration.)

15. What has been said respecting the horses in Canada West is also applicable to those bred on the ranches, where excellent mares of size, color and quality are to be met with which require judicious weeding out and then mating to T.B. horses with bone, power and action .

16. In conclusion we must beg to express our gratitude for the able and cordial advice and assistance rendered us throughout our visit from yourself and the whole Department of Agriculture under your administration. Our thanks are also due to Mr. Fred White, the Comptroller, to Colonel Herchmer, the Commissioner, together with the officers, non-commissioned officers and men of the NorthWest Police, and the many gentlemen throughout Canada who have afforded us so much help.

17. We have postponed replying to your letter in order that we might refer the matter to the War Office with a view to obtaining some instructions for the future. We are now directed to inform you that, "so far as can be seen the horses which have been already bought would appear to justify the purchase of additional numbers annually in the future."

We hare the honour to be, Sir,

Your most obedient servants,

F. G. RA VENHILL, Colonel, R.A., Inspector and Purchaser R. A. Horses.

G. PHILLIPS, Colonel.

THOS. MATTHEWS, B 1st Class,

To the Hon. John Carling,

Royal Horse Guards.

Minister of Agriculture,

Ottawa.

P.S.-Three hundred horses may be bought in Canada next year if they can be obtained within the prices and of the stamp required. F. G. RAVENHILL, Colonel, R.A. 
The following report has been communicated to the Minister of Agriculture:-

\section{ADDRESS TO HORSE-BREEDERร.}

Delivered in the Committee-room of the Agricultural Hall at Islington, at the request of the Council of the Institute for Agriculture, on Wednesday, 2nd March, 1887, by Colonel F. G. Rarenhill, R.A., Inspector and purchaser of R. A. horses, on the occasion of the stallion shows of the Hunters' Improvement and Hackney Stud.Book Societies.

\section{The Duke of Westuinster, K.G., in the chair.}

I have been asked by the Council of the Institute of Agriculture to give a short address to-day on "the Breeding of Horses suitable for Her Majesty's Servico." The present time would appear to be not altogether inappropriate for this purpose, when it is remembered that great efforts are being made in various directions to rouse breeders and agriculturists to the desirability of their recovering for their own pockets a great portion of the third of a million of money going out of the country annually in the purchase of an average of some 17,000 foreign horses imported here for work; all of which we could doubtless rear far better in England. In support of this revival, let me refer you to that show of thoroughbreds at Newcastle, on the 25th of January last, and also to those shows opened in London by the Shire Horse, the Hunters' Improvement, and Hackney Stud Societies, with many other associations formed or forming all over the country, at Lytham in Lancaster, and at Sherborne in Dorsetshire, \&c. This matter is of great public and undoubted military importance, and if anything I can say today will enable the British farmer in his present distress to think of anything to improve his position and brighten his prospects, or further any scheme for benefiting the breed of horses, more especially those required for military purposes, then my objэct will have been gained, and I trust your valuable time may not altogether have been wasted. 
The subject of our British Hor'se supply has been continuously brought to the notice of the public of late years, through the com. mittee called for by Lord Rosebery in the House of Lords, in 1873 ; by that splendid proposal of Lord Calthorpe's in 1875; again by Mr. Chaplin, in the House of Commons, in 1875; subsequently by Sir Frod. Fitzygram, Bart, M.P.; since then General Sir Fred Roberte, Bart., at the Mansion House dinner; Colonel Keith Fraser, in the pages of the Fortnightly Review; Major-General C. C. Fraser, V.C., M.P.; Colonel Russell, Royal Dragoons, with many other officers and civilians, have urged the necessity of some action baing taken, and within the last few days questions in both Houses of Parliament have again been asked. In this country the horso question is everyone's business in general, and nobody's in particular; every Englishman considers he knows more on this subject than his neighbors; he holds his own views, and pretty strong ones they are, whether it be financially, when staking on his favorite for the Dorby, or his choice of a sire for stud purposea. Unfortunately, the Government have no department or official to represent the horse interest in this country as they have for recruiting; all is left to chance, and when a crisis arises, then irresponsible committees have to be organized, and action has to be hurriedly and expressively taken.

Before proseeding further, the question naturally arises as to "what constitutes a military horse." They are distinctly of two different kinds, though not more "warlike" than any other good general purpose horse between 15 hands 2 inches and 16 hands high, in general use all over the country. The first, the most important and most difficult now to procure in any quantity, is that required for riding purposes, with lengthy rein, good shoulders and forehand, good back and loins, as well bred as we can get them; they must walk freely and well, and at 5 years old should stand not less than 15 hands 2 inches high; of these we should have at least three. quarters of the whole supply of 1,800 to 2,000 required in peace time annually for the army, or about 1,500 riling horses. The nocessity, 
therefore, will be understood for our getting as much T.B. blood for this purpose as we can procure. The sec ind, or draught horse, is a compact, short-legged, quick walking, good going van horse, betwoen 15 hands 2 inches up to 16 hands high, for Royal Artillery draught, Royal Engineers and transport purposes. These are more easily procurable all over the world, though in looking for them we prefer a tight, ehort-legged, active horse, and before all things we look to getting one that can walk freely and well, such as one sees trotting about in parcel carts, or walking along a furrow at the rato of four and a half miles an hour.

I will now read to you the particulars laid down for guidance when we are purchasing remounts for the Royal Artillery or Rogal Engineers:-

(1.) The age at which horses are taken is between rising four and rising seven years old.

(2.) The height is nothing under 15 hands 2 inches, and nothing over 16 hands; not less than 8 inches below the knee, or 72 inches in girtb.

(3.) The proportions in which horses are required for the Royal Artillery at present are about half short-legged, blood horses with some length; the other half useful, quick-going, deep, weighty, strong van horses for draught purposes, and half of these must have a turn of speed for the quicker work of Horse Artilley.

(4.) Of the blood horses about one-fifth must have the making of a first.class riding horse with breeding, power, shoulders, action and appearance suitable for carrying an officer, the other four-fifths must be well-bred, active riding horses with shoulders, action, and substance sufficient to carry non-commisioned officers or men.

(5.) Bays, browns, chestnuts, or blacks of hardy color alone taken; no greys, roans, duns, cream colour, or parti-coloured horees are ascepted, and no horses with any material blemish are purchased.

(6.) It is understood that during the month of probation on trial, whilst standing at the dealer's risk, if horses on re-shoeing are found 
below the standard height, with sunken soles, seedy toes, sand cracks, \&c., or are found crib-biting, wind-sucking, or if unsound in the eyes, wind or limb, or vicious, in or out of stable, they will be returned to the lealer. who must send in another suitable horse in exchange.

(7.) Gorernment prefer taking horses that are undocked, but no horses will bo accepted with a very short docked tail.

The age of a horse will be reckoned from the first of May in the year in which it was foaled, and no remount horse will be purchased prior to the 1st October in the year in which it becomes three years old, except under the special authority of the Adjutant-General; or later than the 31th December in the year in which it shall have reached the age of six years. On and after the 1st October, threeyear-old horses will be purchased at four-year-old price.

The standard of height is fixed by the Commissioner-in-Chief. The fitness of horses in point of appearance, strength and action will be determined by the purchasing officer, and their soundness will in each case be certified by an army veterinary surgeon.

The purchase money of troop horses on home service will be paid by the regimental paymaster, under the directions of the commanding officer, and a statement of the particulars of the payments, specifying the age of the horses, the actnal prise paid for each horse, and the average price for the period of the pay-list in which the charges are made, will be inserted in the pay-list. The charges will be supported by receipts from the dealers for the amount paid; the price at present paid is $£ 45$ per horse.

Dealers from whom horses are purchased may receive for each hore delivered to and passed at the headquarters of the corps, a commuted allowance as follows:-

In the case of corps stationed in Ireland, 16s. for each horse.

In the case of corps stationed in Great Britain, 27s. for each horse.

In all cases the dealers will be held responsible for the risk and expenses incurred, should the horse be injured on this journey, or prove unfit for service on arrival at the regiment. 
The following are some further instructions for our guidance :-

Examination of mouth and eyes; measuring and examination from near side; cannon bone; arms and thighs.

Every horse about to be examined should be taken under a shed, archway, or to the stable door, where the light is suitable. The veterinary surgeon first examines the mouth in order to determine the animal's age, and at the same time he sees that there is no defect in the jaw or teeth. The eyes should then be carefully inspected, and, if they are found to be sound, the horse may be led out for examination by the purchasing officer, care being taken that no "gingering" is practiced. Any good-looking five or six-year-old horse submitted at troop price should be treated with suspicion. The purchasing officer will measure the horse, note the colour, and observe from his near side how he stands all round on his feet and legs; whether he looks small or tied in below and at the back of the knee. Every troop horse ought, if possible, to measure not much less than eight inches round the leg close under the knee, and the bigger and flatter he is here the better, for it is at this point that strength is specially required. The cannon bone should be short and, together with the tendons, distinctly defined; the arms and thighs long and muscular, and the joints not small, but clean and well developed.

KNeEs, elbows, hind Legs, hocks, PAsterns, Fetlocks.

The knees should not be back like those of a calf, nor too much bent over like those of an old cab horse-though of the two evils it is preferable that a horse should stand a little over at the knee rather than back; the elbows should be free; the hind legs must be well placed under the body; the hocks not too straight, yet not sickled or bent; they should be clean, well cut, and free from any enlargement inside or out, or from any tendency to curb or thoroughpin; the pasterns must neither be too short or upright, nor too long and sloping; the fetlocks shou'd not show signs of work, too much play either in these joints or in the pasterns produces overshooting, which is a decided weakness. There are occasional swellings on 
these part., especially in young stock, arising from sickness, debility, or contusions, which are sometimes mistaken for unsound. nees.

\section{FEET .}

The feet should be of the same sizo, round in shape at the soles, with good open heels, not small, contracted or flat; the hoofs should stand as nearly as possible at an angle of $50^{\circ}$, and they must not be brittle, blocky, or ring.

IEAD.

In considering the shape of the head, it is important to note the position of the eye, which should not be too low down, too far forward, or too small; the last named defect is call "pig-ejed." The forehead should be broad and the countenanco kind. Long big ears, provided they are not lopped or drooping, are preferable to such as are small, curved, or pointed, though theso latter are no doubt prettier. The head should be well set on to the neck at an anglo not too oblique or acute, and there should be sufficient room under the jowl. The nostrils should be large and open. The lips not drooping or relaxed. The jaws and teeth evenly plased above one another.

\section{NECK-SHOULDERS.}

The neck should be convex and not concave, which latter is a structural defect indicating weakness and is called "ewe-neck." It should be well set into the shoulders, and these should be clearly defined, sloping well back from the points to the withers. 'The points of the shoulders ought not to be heary. Fine high withers are a great attraction, and onable the saddle to retain its proper position. It is true that horses with thick or flat withers, or short, upright shoulders, msy be suitable for dranght, prorided they have good action.

\section{BARREL .}

The barrel should be deep and arched bohind the elbows, thus 
affording space for the development of all vital organs. Every troop horse should girth as much over 70 inches as may be procurable.

\section{BACK AND LOINS.}

A long hollow back should be avoided. A "roach back"-though ugly-is strong. The loins should be as broad and deep as possible.

TAIL.

The tail should be set on high enough to be symmetrical. Fine hair in the mane and tail shows breeding. The greater the length from nose to withers and from hip to croup the better. Care should be taken that the withers, shoulders, back and chin are free from material blemishes.

EXAMINATION OF CHEST AND FORELEGS, \&C., FRON FRONT.

While the horse remains standing, the position of the purchasing officer may be changed from the near side to the front, so as to note how he looks from this point of view, and to see how he stands, whether he has sufficient breadth of chest. There should be no blemishes about the knees, no enlargements or scars from brushing inside the fetlocks, no marks from speedy-cutting under the knees, and the situation of splints, if there be any, should be particularly noticed.

\section{SHANK BOne.}

The shank bone should be straight and square under the body, not bandied or twisted, but supporting properly the weight of the body. The toes should neither be in nor out. Ose fuot turned out or in is unsatisfactory, because it indicates uneven action with an uneven bearing of weight of the body either at rest or in motion.

\section{EXAMINATION OF OFF SIDE AND REAR.}

The off side must be examined in detail in the manner already specified for the near side. The purchaser should then walk round to the rear of the horse, and notice if the hocks are very much in or bowed out-of the two the former is preferable. A horse ought to 
be broad across the hips, and these must be even and level, the fork should not be too much split up.

\section{WALKING.}

The horse must now be led off at a walk; the purchaser should keep behind him and note as bo goes from him if he turns his toes out or in, or whether there is too much play outwards or inwards in the hocks. If he crosses his hind or fore feet or legs he should be rejected. As the horse turns, he should be narrowly watched, and as he walks past it should be seen that he puts his feet down even and fair. The action of his fetlocks and pasterns must also be noted. If there be decided knuckling or overshooting here, he must not be taken. The walk should be free, the stride long and clear, the hocks not bent, no dragging or eatching of the hind or fore toes along the ground, no "forging" from overreaching. When the toes are out, the elbows are in, and the latter being tied, the fore action is often cramped and contracted.

TROTTING.

The animal can now be trotted, and as he goes from you it must be noted if he crosses his fore or hind legs, which is dangerous; if he dishes or turns one or both feet in or out, it is objectionable. Should he roll in his stride, this may denote damage in the loins or hocks, and the attention of the veterinary surgeon, who is responsible for soundness, would naturally be called to these points. If there is any eatching in the action of the hind legs, he should be run sharply backwards to ascertain that there is no paralysis; as the horse passes it should be seen that he has good knee and hock action.

\section{SPEEDY·CUTTING.}

Speedy-sutting arises from faulty conformation of the fore legs, and also from a peculiar kind of high action in front. It is the act of striking one fore leg just below the knee with the inner quarter of the other fore foot, a most acutely painful and dangerous thing, for which a horse should be at once rejected. 
REJECT FOR ANY ONE WEAK OR BAD POINT.

Although a horse is a good coloured, well topped, good going, taking animal, jet, if he bave one decidedly weak or bad point he must be refused; but here the veterinary officgr's opinion will be most valuable, as many hors ss may be quite serviceable, though not absolutely sound and may "in times of need" be fully equal to the requirements of a compaign, and do much hard work.

\section{RESTRIOT PUROHASING TO 25 A DAY.}

Purchasing horses is laborious work, and by the time that 25 or 30 have been examined, passed, and registered, the officers enuployed will have exhausted much power, both of eye and brain: When continued daily, purchasing should be restricted to 25 a day; then working for a special object, seventy a day have often been examined, but it is not practicable to do justice to such a number. Very good and very bad animals are soon disposed of; it is the middling and doubtful horses which take up the time: further it may be ac. cepted as a general rule that the first impressions of a horse are the most correct and lasting.

\section{EXAMINATION ON BEING RECEIVED INTO DEPOT AND RETURNED IF UNFIT.}

On remounts being received into depots they should be lunged at once-if fit for it-to try their wind, unless this has been done previously, and they should also be generally re-examined under the direction of the veterinary surgeon. Their shoes should be taken off and the feet examined for sand cracks, seedy toes, sunken soles, \&c. They should be carefully re-measured and registered, and if, on being re-shod, they are found below the necessary height, or if any unsoundness is detected in ejes, feet, wind, or limbs, or if they are found vicious in or out of the stable, they should be returned. On the other hand, if fit, they should be branded on the hoof, in accordance with the regulations on that subject.

Horses in general fall naturally into two great divisions-riding and draught-according to the particular way in which their physi- 
cal formation and breeding enables them most advantageously to apply their force. A man who has a knowledge and appreciation of horses can tell to which of these divisions any given animal belongs; but it may be laid down as a general rule that a riding horse should be better bred and should have a more sloping shoulder, a longer forehand, with more floxible and lighter action than a draught horse. Again, these two divisions are conveniently subdivided, the first into two, the second into six classes, making altogether eight classes, which would stand as follows:-

1. 1st class riding horses for officers, staff sergeants, trumpeters, and the riding establishment.

2. 2nd class riding horsos for detachments of Horse Artillery and Non-Commissioned Officers of Field Artillery.

3. Horse Artillery lead and centre horses.

4. Horse Artillery wheelers.

5. Light Field Artillery lead and centre horses.

6. Light Field Artillery wheelers.

7. Heary Field Artillery lead and centre horses.

8. Heary Field Artillery wheelers.

The difference between 1st and 2nd class 1iding horses is one merely of breeding, appearance and degree; the same may be said in comparing classes 3 and 5, and classes 4 and 6 respectively. Heavy lead and wheel horses (classes 7 and 8) differ from light lead wheel horses (ciasses 5 and 6 ) in having more weight and power. As regards lead and wheel horses, whether for Horse or Field Artillery, the low size, thick set horses should be selected for wheelers, those which are higher being told off as centre or lead horses, thus ensuring a regular and upward line of draught. Where practicable the hand horse of a pair should be higher than the near side one.

EXCESS OF RIDING HORSES NECESSARY.

From the days of Wellington onward (vide the "Wellington De. spatches" $22 \cdot 6 \cdot 1809,-27-6-1809,-258-1809,-5 \cdot 2-1811,-10-2-1813)$, 
there has always been a difficulty in obtaining sufficient riding horses, and when purchasing for the service, a surplus of Officers' and other riding horses may advantageously be taken, for if properly selected, it would be impossible to utilizo them for draught purposes.

\section{EXCESS OF WHEELERS.}

Again, if every draught horse which is bought be powerful enough to be used, when necessary, as a wheeler, the service would be thoroughly efficient.

Having detailed the class of horse required for the Royal Artillery and Royal Engineers, I now submit directions drawn up for the guidance of Cavalry officers in the purchase of horses for their branch of the service.

Of course it is not as easy to judge of the future make and shape of a young horse as it is to judge of an aged one, whose conformation is fully developed. Still, there are certain defects which are as easily seen in young horses as older horses; and these faults, at least, may be avoided by a fair amount of care, practice and judgment.

Especial care, indeed suspicion, is also needed, when a goodlooking horse of 5 or 6 years old is offered at the troop price. The chances are that there is some fault, which others have already found out.

A horse should be rejected for any ore really bad fault. The greatest strength of a horse is limited by his worst point. Horses are often bought because they possess one or more very good points. This is a wrong principle in buying. The selection of horses should begin by rejection for bad points. Bad points are, of course, in a great measure, a question of degree. Discretion is needed in rejecting as well as in buying.

1. Size. Four-year.olds, i.e., three off after October 1st, should not be less than 15 hands $0 \frac{1}{2}$ inch nor exceed $15 \cdot 1 \frac{1}{2}$ for light cavalry.

For medium they should not be less than $15 \cdot 1$ nor over $15 \cdot 2$.

For heavy cavalry not less than 15.2 nor over $15 \cdot 3 \frac{1}{2}$. 
N.B.-In measuring a horse or judging of his height and size by sight, take care that he stands on a level with yourself. Dealers generally stand a horse, if undersized, on higher ground, or if over size, on lower ground than the intending purchaser.

2. Want of a fair amount of breeding ehou'd be an absolute bar.

3. Reject a horse with a big coarse head.

4. Reject a horse with a small sunken eye. They are generally obstinate and sulky.

5. Reject a horse of a colour light of the sort.

6. Reject a borse with a long slack back. It will not carry weight.

7. Reject a horse with a hollow back. The formation is weak.

8. Reject a horse with flat sides. They will not do work or look well.

9. Reject a horse with a slack loin, i.e., undue length between the last ribs and hind quarters (sacrum). They are often bad feeders, and will run up light with work.

10. Reject a horse with a light loin, i.e., want of breadth over the loins. They run up light with work.

11. Reject a horee with scraggy hips. They never do credit to feeding, particularly if also slack in the loins.

12. Reject a horse with a bad girth, i.e., "light through the heart." This formation will always cause trouble in saddling.

13. Reject a horse with a thick or short neck.

14. Reject a horse unless it has a good rein. With a clumsy neck the head is in consequence badly set on. Without a good rein a horse will never break well.

15. Reject a horse with very low withers. The saddle will be apt to work forwards, and the "rein" will probably be deficient, and the leverage for the muscles of the forehand is defective.

16. Reject a horse if very short. There is not room enough for the kit. 
N.B.-To see the above points $(1-16)$ stand on the side and form your opinion before the horse moves off.

17. Reject a horse with a narrow or shallow ehest. There is not sufficient capacity for the lungs.

18. Reject a horse with fore legs very close together. This and the former defect generally go together. To see these points stand in front.

19. Reject a horse whose fore legs are not straight. They will not stand wear. Stand behind the horse as he walks away from you, and you will be able to notice these defects, if they exist.

20. Reject a horse which is light below the knee, especially if immediately below the knee. The conformation is essential weak.

21. Reject a horse with long, or with short, or with upright pasterns. Long pasterns are subject to strains. Short or upright pasterns make a horse unpleasant to ride, and, on account of extra concussion, are apt to cause ossific deposits.

22. Reject a horse with toes turned in or out. The twist generally occurs at the fetlock. Toes turned "out" are more objectionable than toes turned "in." When toes are turned out, the fetlocks are generally turned in, and animals so formed are very apt to cut or brush. Both, however, are weak formations.

23. Reject a horse whose hind legs are too far behind. Good propelling power will be wanting, and disease as a result may be expected in the hocks.

24. Reject a horse which goes either very wide or very close behind.

25. Reject a horse with very straight or very bent hocks. The former cause undue concussion, the latter are apt to give way.

26. Reject a horso which is "split up," i.e., shows much daylight between his thighs. Propelling power comes from behind, and must be deficient in horses without due muscular development between the thighs. 
27. Reject a horse with flat feet or over-large feet, also with very small feet. Medium size are the best.

28. Reject a horse with one foot smaller than another.

Action must be light, easy, free, and straight. Reject a horse that crosses his legs in walking or trotting. He will be unsafe. Freedom, power to move easily along, is the great point in a young horse. Knee-action is not essential ; it will come with the bit and breaking.

A good walk is absolutely essential. Reject a horse shat does not walk well ; he is never pleasant to ride. If a horse walks well, he will probably trot well; but a horse may trot well without walking well.

To ascertain whether the action is true and straight, stand behind the horse as he walks and trots away from you. You cannot ascertain this important point by standing on the side.

Never omit to stand behind a horse as he walks away.

A good sloping shoulder is an important item in a riding horse, but bad action may co-exist with a good; and vice versà, good, free action may cc-exist with a somewhat straight shoulder.

Reject a horse which is straight in the shoulder and long from the point of the shoulder to the upper part of the forearm. This formation places the fore legs too much under the horse, and makes him unsafe to ride.

You may have a plain horse, even if all the above very apparent defects are absent, but you will at least have a serviceable one.

Having first cf all kept clear of all absolute defects such as the above, then select your horses for the presence of good, serviceable, and handsome points, and eary, free, graceful carriage.

But, I repeat, begin by rejection for any one positively bad defect. The greatest strength of a chain is limited by the strength of its weakest link. 
In purchasing horses, it is a great point not to lose time. If yous see any one radical defect, reject the horse at once. The dealer will, of course, try and persuade you to do otherwise, and will call your attention to some very good point or points in the really defective animal.

Don't lose time. If you do you may get pressed for time, may be obliged to make only cursory inspection of animals presented late in the day, and may end by buying inferior horses, which jou would have rejected in the morning.

It should be noticed that only a few greys are required (viz., about 50 a year) for the 2 nd Royal Dragoons.

Mares are purchased as well as geldings, but no stallions. Horses which are broken are preferred, but a troop horse purchased cheap, whon young, is not necessarily a perfectly broken animal with manners and accomplishments, so long as they are halter broken. and appear kind and temperate.

No horse is ever taken with a blemish of a material nature.

It has been represented to me on several occasions, and people have been writing to the papers on the subject, that GJvernment ought to pay more for their horses; indeed, there is a proposal in one of the weekly agricultural papers of the week before last suggesting that the price for horses should be increased to $£ 50$ per head. The whole question is one of supply and demand, and is dependent on the state of the market.

I have, therefore, drawn out the following table, giving some figures on the subject :- 
Retuan showing the numbers of horses in Great Britain not omployed in agriculture, \&c., during the past fow years, taken from the agricultural returns; also the number of horses imported into England, the numbar of horses in possession, and the prices paid per head, during a series of years, by the General Omnibus Company, also the prices paid by Government for their horses during the same period.

\begin{tabular}{|c|c|c|c|c|c|}
\hline \multicolumn{6}{|c|}{ NUMBER OF HORSES. } \\
\hline \multirow{2}{*}{$\begin{array}{l}\text { Years ending 31st } \\
\text { Decembor, }\end{array}$} & \multirow{2}{*}{$\begin{array}{c}\text { Imported } \\
\text { into Great } \\
\text { Britain. }\end{array}$} & \multirow{2}{*}{$\begin{array}{l}\text { In the } \\
\text { whole of } \\
\text { Great } \\
\text { Britain. }\end{array}$} & \multicolumn{2}{|c|}{$\begin{array}{l}\text { The General Omni- } \\
\text { bus Compsny. }\end{array}$} & \multirow{2}{*}{$\begin{array}{l}\text { Paid by } \\
\text { Government } \\
\text { for troopers. }\end{array}$} \\
\hline & & & $\begin{array}{l}\text { In Posses- } \\
\text { sion. }\end{array}$ & $\begin{array}{c}\text { Prices } \\
\text { per head. }\end{array}$ & \\
\hline & & & & $£$ \& d. & $£ \quad £$ s. \\
\hline $1876 \ldots \ldots \ldots \ldots \ldots \ldots$ & 41,148 & .......... & $\ldots \ldots \ldots .$. & $\cdots \cdots \cdots$ & $\cdots \cdots \cdots$ \\
\hline $1878 \ldots$ & $\begin{array}{l}30,524 \\
26,521\end{array}$ & $\cdots \cdots$ & 7,674 & 51 & 40 to 4810 \\
\hline * $1879 \ldots$ & 15,246 & $1,080,000$ & 6,914 & $\begin{array}{lll}39 & 8 & 10\end{array}$ & 30 i6 $48 \quad 10$ \\
\hline 1880 & 9264 & $1,092,272$ & 6,935 & $35 \quad 1 \quad 4$ & $\begin{array}{llll}40 & \text { 《 } & 48 & 10\end{array}$ \\
\hline 188 & 9,050 & $1,231,000$ & 7,291 & & $\begin{array}{llll}40 & 4 & 45 & 0\end{array}$ \\
\hline $1882 \ldots$ & 8,827 & $1,413,578$ & $7,53 i$ & $\begin{array}{lll}35 & 6 & 3\end{array}$ & $40 \quad 4 \quad 45$ \\
\hline 1883 & 9,627 & $1,410,596$ & 7,695 & $\begin{array}{lll}35 & 1 & 0\end{array}$ & $40 \quad 16 \quad 45$ \\
\hline 1884 & 12,928 & $1,414,377$ & 7,944 & $84 \quad 14 \quad 9$ & $\begin{array}{lll}40 & \text { ' } & 45\end{array}$ \\
\hline $1885 \ldots$ & 13,023 & $1,405,789$ & 8,124 & $\begin{array}{lll}34 & 5 & 8\end{array}$ & $\begin{array}{llll}40 & 45 & 4\end{array}$ \\
\hline $1886 \ldots \ldots \ldots$ & 11,027 & $1,425,359$ & 8,589 & $\begin{array}{lll}33 & 17 & 5\end{array}$ & 40 " $45 \quad 0$ \\
\hline
\end{tabular}

* In this year the supply of English horses was noted as much improved.

From this it will be seen that between 1879 and 1886, although the ntumber of horses estimated as in Great Britain has been steadily increasing, yet the average number imported during those years has been more or less decreasing, that whilst the numbers in possession of the largest employers of horses in the kingdom next to the Government, the General Omnibus Company, has been steadily rising owing to increased traffic, yet the prices that have been paid during this courso of years has as steadily decreased from $£ 39$ 8s. 10d. in Juno. 1879 , to $£ 3317$ s. per head during the year ended December, 1886, whilst the prices paid by Government for a similar period have also decreased, but stand in a higher ratio than those purchased for private use. 
It is overlooked that the 2,000 remounts annually required to keep up the present Government supply are but a very small proportion of the requirements of the public; the question of value then, and prices to be paid is one of public demand, and not one in which the Government would be expected to pay a larger price than the market valuo decides on.

We have to congratulate ourselves that we are producing more horses in this country, doubtloss, cwing to the increasing interest taken in the matter, the action of the different societies, and the deficiency which has become apparent; without doubt the population has increased and the public wants must be supplied, but the population cannot have incressed in proportion to the extent that the number of horses have as gathered from this return.

The question now presents itself, are the numbers of horses we are producing of the right sort for genoral and military purposes? I think not.

What the army requires, what the public needs, and what every man uses who can afford it, whether for hunting or driving, is a large \&upply of the up-standing, three parts bred, general purpose horse, of good substance and colour, between $15 \cdot 2$ and 16 hands high, such as used to be bred in numbers by our fathers for general work in the stage coaches all over England, and which the railways have caused to disappear.

Such a horse can only be produced by the continuous and more general use of T. B. sires all over the country, and we must do something to produce these within reach of farmers in breeding districts, at as low a fee as can possibly be arranged for ; the Royal Agricultural Society of England, also the Hunter's Improvement Society, is doing much in this direction, but the need for good is so widespread that it should go further, and the money now given in Queen's Plates annually for racing, which was originally given "to improve the Breed of Horses in England," should be diverted for this purpose, and as it comes out of the pockets of the ratepayers, it lies with you all to seo that it is thus properly applied. 
My own idea is that the money now given for Queen's Plates would be more beneficially used in the shape of subsidios by apportioning it out to the Royal Agricultural, the Hibernian,Caledonian, the Hunter's Improvement, and other kindred societios, to be given away in premiums for good stallions, provided they come up to a certain standard of excellence, are sound and will be available in fixed districts in Great Britain and Ireland during the ensuing season at small fees.

A regular list of these horses and the districts they will be in should be registered in the offices of the societios where, on application by the owners of mares, there would be no difficulty in learn. ing the nearest available sire.

In the choice of districts, select those near large railway junctions or stations to enable men with mares to send them in from surrounding villages, such as Aberdeen, Ballinasloe, Beverley, Bridgewater, Cardigan, Carmarthen, Chester, Clonmel, Cockermouth, Cornwall, Denbigh, Dumfries, Doncaster, Exeter, Gloucester, Hereford, How. den, Kendal, Lincoln, Lytham, Limerick, Mey, Co. Tyrone, Mullingar, Northallerton, Northampton, Penrith, or Kirby, Stephen, Ripon, Sherborne, Warwick, Wigton, York.

If this money is not to be given for premiums through the large societies, ss has been suggested, I feel sure, if a capable man were handed over that $£ う, 000$ now given for Queen's Plates each year, he wculd arrange to spend it mure profitably for the country than it now is. Let him make a commencement by-

Purchasing 4 thoroughbred stallions at $£ 500$ each. $£ 2,000$ do 4 roadsters 300 do 1,200

Hire 4 thoroughbred stallions at $£ 200$ for each season ..................................................... $\quad 800$

Hire 4 roadsters at $£ 100$ each........................... 400

Expenses, say........................... 600 
Any district that can guarantee 70 serviceable useful mares for the eight thoroughbreds at a fee of $£ 2$ each, and of 60 good mares for the eight roadsters at $£ 210 \mathrm{~s}$. each, the manager would arrange to send the mares, realising on account of fees, $£ 1,120$ for thoroughbreds, and $£ 720$ for the roadsters; total, $£ 1,810$, which should well cover all expenses, as follows: -

Groom and attendant at each station, $£ 120 \times 8$........ $£ 960$

Keep of 16 horses, contingents, rental $£ 1$ per week... 832

Total

These figures might possibly work out more favorably.

There is no doubt a great scarcity of fit mares for breeding from throughout the country, but there is also a greater scarcity of good reliable stallions; and regarding the deficiency of mares, I believe if good sound horses were forthcoming, farmers would soon get and keep mares, provided they could get a sale for their young stock, which I will touch on presently.

Gentlemon bave been in communication with me on the subject of helping furmers to procure mares. Frank Lovell, Esq., of Hincheslea (a rare horseman) writes :-

"Individual breeding is hopeless, but associations might do much; no amount of prizes to stallions will increase the breed, which is what we want; what we ought to have is some tens of thousands of Horse Artillery mares, to add to the bone and power of our two often wredy half.mile T.B's, or before long we shall all have to walk. A councy organization always ready to take good mares and always having at command the services of one or more approved stallions would be an invaluable resource; for all gentlemen having znares to part with, as well as for the breeding farmers who now are at their wits' end to know where to look for good stallions; if woll managed and supported the business ought to pay, but if only 2nd or 3rd class horses are provided, numbors of animals are proluced; whilst every farmer, horse dealer, and tradesman in England is benefited." 
This gentlaman submits for our consideration the following proposals :-

"(1.) Every county to support its own horee-breeding establishment (some more than one).

"(2.) Lord Lieuterants and principal gentlemen be asked to start and support it.

“(3.) All cast mares from the service suitable for stud to be offered to it: and artillery and other government mares purchased.

“(4.) Annual, biennial or triennial sales without reserve.

"(5.) Details and establikhment of expenditure and eystem to be carefully prepared.

"(6.) Government to be invited to assist in all ways possible.

"(7.) The proposition, when placed before the public, to have all the best names attached to it.

"(8.) Annual subscriptions of county gentlemen $£ 10$ to $£ l$ each."

Then 1 have another suggestion from a gentleman who hunts in the shires, and who is getting together a local society to purchase at a moderate rate, any sound, fit mares procurable, to retail to breeders in their hunting countries. He also suggests that some arrangement should be made by which the Government should permit troop mares, after a few years in the service, to be resold to farmers and breeders at a reduced rate; then other societies in some of our large horae-prolucing countries have been in correspondence with me, in their endeavor to get Government sanction that Iscal Agricultural Committees should be permitted to come, select and purchase the best of the troop mares annually for breeding purposes.

Gentlemen, in the interests of the service, seeing that a large proportion of troop animals are mares, I do not consider this could be done; but I have suggested somewhat the following-when troop mares are being cast for certain causes rendering them unfit for the cervice, but still no hereditary or other breeding defect about them, that such sale should be notified to any local societies whochoose to 
be constituted in a responsible way, and every facility should be given for members to previously inspect them and, on the day of public auction sale they could bid for the animals. After this bas been done for a term of years, say five, such societies would be in a position, through the Royal Agricultural or other societies, to go to Government and represent that during the past term of years, a certain number of horses have been purchased at an average price, and then ask what ratos Governmont could permit mares a few years younger to be purchased. Possibly some arrangement could be arrived at in this way, as then Government and the public would have, certain figures before them as valuation data to go on.

If any farmer or breeder requires a mare and will pay for it, will communicate with me at 61 , The Common, Woolwich, telling what he requires, and the price he wants to give for it, I will see what can be done towards procuring the mare for him.

We must now consider what is to be done as to the disposal of the produce, my idea being you should only breed for the best; there will be plenty of misfits, it is no use trying to breed a good horseon soil and climate that is unsuitable, or on pasture that will not carry a horse; do not endeavor to breed a troop horse, try and produce an animal that will grow into the best hunter, if he misses that mark, and has not the appearance and action for a first-class harness horse he will make a trooper, you have, therefore, two first-class markets to think of where high prices can be realised, before you hope to sell to the Government.

There is a proposal circulated by Mr. Gilbey in a letter to the papers a fow days since, that Government should purchase two. year-olds, graze them themselves on their own grasslands until old enough to issue out to the troops; another member of the House of Commons just lately asked if Government could not arrange that their purchasers should advertise their dates of purchasing in different districts? I foresee no difficulty in carrying out these arrangements, provided the Government think it desirable to do so, and doubtless some such plan in the existing state of things would do 
much to help the farmer in his struggle for existence, without much, if any, additional cost to the country.

I should recommend breeders putting a three parts bred, or even half bred, strengthy, long, low, wide, good colored, good constitutioned, hereditary sound mare, of from 15.1 to 15.3 in height, not too old, with good limbs and lengthy forehand, to good colored, good limbed sound T.B. stallions.

If any man has by him a lighter, botter bred, active, good colored, well dispositioned mare on short legs, put her to a pedigree roadster or hackney stallion of undoubted family, color and soundness.

Should you not know where to find stallions in your particular district, apply for information to the secretaries of either the Hunter's Improvement or Hackney Horse Societies, who will, doubtless, be able to afford you the necessary directions of owners of horses who possess sires. 


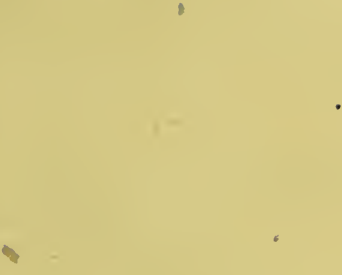


